\title{
Heterotrophic Utilisation of Mucilage Released During Fragmentation of Kelp (Ecklonia maxima and Laminaria pallida). II. Differential Utilisation of Dissolved Organic Components from Kelp Mucilage
}

\author{
M. I. Lucas*, R. C. Newell* and B. Velimirov** \\ Department of Zoology, University of Cape Town, Rondebosch 7700, South Africa
}

\begin{abstract}
Mannitol, and to a lesser extent sugars plus alginates, released in mucilage during fragmentation of kelp is utilised by bacteria in the water column. Incubation of $6.4 \mathrm{~g} \mathrm{l}^{-1}$ dried mucilage from Ecklonia maxima and $7.2 \mathrm{~g} \mathrm{l^{-1 }}$ from Laminaria pallida at $10^{\circ} \mathrm{C}$ results in a utilisation of more than $50 \%$ of the mannitol within $48 \mathrm{~h}$ whereas alginates plus sugars reach $50 \%$ of their initial concentration in 6-10 d. There are, however, marked seasonal differences in conversion efficiency. In the winter, incubation media were colonised by small cocci and rods and the increase in biomass of bacteria per unit carbon loss was approximately $12 \%$. Incubation of the same mucilage from $L$. pallida in seawater collected during the summer, however, resulted in the development of a population of large rods with a biomass about $3 \times$ that of the smaller rods which predominated in the winter incubation experiments. The increase in biomass of bacteria per unit carbon loss amounted to as much as $29.4 \%$ in the summer incubation experiments. The annual dry weight of mucilage production during fragmentation from a small kelp bed of $700 \mathrm{ha}$ is $1458.38 \times 10^{4} \mathrm{~kg}$ and estimated to be capable of supporting a dry biomass of approximately $30 \times 10^{4} \mathrm{~kg}$ bacteria and $3 \times 10^{4} \mathrm{~kg}$ dry biomass of flagellates and ciliates. The high density of filter-and deposit-feeding organisms which characterise the kelp bed suggests that the community as a whole is largely dependent on the flow of energy through these initial stages of the decomposer food chain based on kelp.
\end{abstract}

\section{INTRODUCTION}

Most studies on the dynamics of dissolved organic matter by micro-organisms have been based on measurements of the rate of turnover and microbial uptake of specific ${ }^{14} \mathrm{C}$-labelled substrates under chemostat conditions. Strickland and Parsons (1962), Wright and Hobbie $(1965,1966)$, Hobbie and Wright (1965), Vaccaro and Jannasch (1966), Hobbie (1967), Williams (1970), Williams and Gray (1970), Gordon et al. (1973), Crawford et al. (1974), Iturriaga and Hoppe (1977), Moshiri et al. (1979) and many others have used this approach in an extensive series of studies of the uptake of a variety of substrates by microheterotrophs from

\footnotetext{
- Present address: Institute for Marine Environmental Research, Prospect Place, Plymouth PL1 3DH, England

- Present address: Lehrkanzel für Meeresbiologie und Ultrastrukturforschung, Währinger Str. 17/VI, A-1090 Wien, Austria
}

both marine and freshwater ecosystems. They have shown that low-molecular weight compounds such as glucose and acetate have a high rate of uptake and short turnover time compared with compounds of higher molecular weight (Ogura, 1975), but that there is a great variability in $V_{\max }$ and turnover time (T) both with locality and time (Hobbie, 1971). Again, Crawford et al. (1974) have shown that although amino acid uptake by bacteria in an estuary may account for significant bacterial production, turnover times varied both seasonally and according to the type of amino acid used as a substrate. Wright (1975) and Wright and Shah (1975) have also found that the turnover time of glycolic acid may vary from 7 to $2,000 \mathrm{~h}$, the most rapid rates occurring in surface waters.

One of the difficulties in the extrapolation of such data to natural conditions is that both the communities of microheterotrophs and the dissolved organic matter available to them as substrates released from phytoplankton (Fogg, 1958, 1966; Hellebust, 1965; 
Nalewajko, 1966; Anderson and Zeutschel, 1970 Thomas, 1971; Choi, 1972; Berman and Holm-Hansen, 1974; Smith, 1974) and marine macrophytes (Sieburth, 1969; Newell et al., 1980) are frequently very complex and may vary seasonally (see Linley et al., 1981). As Williams (1973; see also Fenchel and Jrrgensen, 1976) has pointed out, unless the heterogeneous populations of bacteria in natural waters have identical kinetic constants ( $V_{\max }$ and $K_{s}$ ), utilisation of complex substrates by the mixed assemblage as a whole may not be accurately described by the Michaelis-Menten equation. Use of the Lineweaver-Burk plot may then lead to serious errors in estimates of turnover time $(T)$ for the low concentrations of dissolved organic substrates which occur under natural conditions in the open sea.

The rate of heterotrophic utilisation of dissolved organic matter released by macrophytes such as kelp is rather easier to estimate since, unlike conditions in the open sea, relatively high concentrations of mucilage may be released from the tips of the frond during fragmentation and the loss of specific chemical components may then be directly analysed chromatographically. We have recently shown that as much as $25 \%$ of the energy production by a small kelp bed is released as 'dissolved' organic matter during fragmentation. The chemical composition comprises some $4.74-5.27 \%$ protein, $0.17-0.18 \%$ fat $7.17-7.56 \%$ sugars plus polyols, $4.77-5.01 \%$ alginate and 4.6-7.2\% laminarins with $69.8 \%$ ash (Newell et al., 1980). Such mucilage may dominate the dissolved organic matter available for microheterotrophic activity in nearshore waters; it clearly represents a complex substrate whose components are not only different from those released by phytoplankton, but may vary seasonally and have very different individual rates of turnover according to their chemical composition and molecular weights

Although glucose is the dominant primary photosynthate released from phytoplankton (see Hobbie and Wright, 1965; Vaccaro and Jannasch, 1966; Wright and Hobbie, 1966; Hobbie, 1967), its equivalent in kelp is the acyclic polyol D-mannitol which is released together with substantial quantities of amino acids, hexoses and complex structural polysaccharides (Newell et al., 1980). There is, however, growing evidence that microbial communities fail to develop fully in the presence of single substrates such as glucose (Ducklow, 1977) or mannitol (Linley et al., 1981). It was therefore necessary to follow synchronously the rate of incorporation of several components of kelp mucilage into microbial biomass in our incubation experiments. The results suggest that the utilisation of the components of kelp mucilage may vary according to their molecular complexity and degradation, as well as the energy and nutritional requirements of the complex heterotrophic community which develops on kelp mucilage (Linley et al., 1981).

Measurement of the rate of incorporation of the principal biochemical components of the mucilage, coupled with quantitative studies on the succession of micro-organisms associated with its degradation, then allows calculation of the energy flow from primary production through the microheterotrophic community associated with kelp beds without recourse to assumptions on the kinetics of microheterotrophic activity at low substrate concentrations.

\section{MATERIAL AND METHODS}

Samples of $40 \mathrm{ml}$ were taken each $24 \mathrm{~h}$ during the course of the incubation experiments described in the previous paper (Linley et al., 1981). The samples were then freeze-dried, weighed and subsequently analysed for total and organic carbon, total carbohydrates (less polyols) and nitrogen. Our procedure also allowed analysis of component polyols and hexoses, including alginates.

\section{Total and Organic Carbon}

A weighed sample of approximately $50 \mathrm{mg}$ of freezedried mucilage was dissolved in $10 \mathrm{ml}$ carbon-free distilled water. A sample of $100 \mu \mathrm{l}$ was then injected into a Beckman Model 915-A TOC Analyzer fitted with a halogen scrubber and the total carbon value obtained from a curve plotted from glucose standards. It was necessary to use rather higher concentrations of dissolved material to estimate the inorganic carbon content. A weighed sample of $50 \mathrm{mg}$ freeze-dried material was dissolved in $2 \mathrm{ml}$ carbon-free distilled water and $200 \mu \mathrm{l}$ injected into the phosphoric acid inorganic channel of the analyser. The difference between the total and inorganic values then gave the organic carbon content of the sample.

\section{Total Carbohydrates Exluding Polyols}

Simple sugars, oligosaccharides, polysaccharides and their derivatives, excluding polyols, were estimated colorimetrically from the phenol-sulphuric acid reaction described by Dubois et al. (1956). A sample of $2 \mathrm{ml}$ incubation medium was pipetted into a colorimetric tube followed by $1 \mathrm{ml} 5 \%$ phenol in water. Then $5 \mathrm{ml}$ concentrated sulphuric acid was added rapidly and directed onto the liquid surface to improve mixing. The tubes were allowed to stand for $10 \mathrm{~min}$, then shaken and incubated for $15 \mathrm{~min}$ at $25^{\circ}-30^{\circ} \mathrm{C}$. The absorbance of the characteristic yellow-orange colour 
may then be measured at $490 \mathrm{~nm}$ for hexoses and $480 \mathrm{~nm}$ for pentoses and uronic acids. In practice, rather different standard curves are obtained for different sugars, so that in the case of total carbohydrate estimations of mixed sugars, it is necessary to prepare standards of the mixed sugars in the proportions which they are likely to occur in mucilage. One of the difficulties in the use of such mixed standards in the analysis of our incubation media is that different components of the carbohydrate pool may be used at different rates whilst the use of a calibration curve of mixed standards is only valid if each component remains in the same relative proportion throughout the experiment. We have therefore expressed total carbohydrate values as the 'glucose equivalent' obtained from a series of glucose standards only.

\section{Polyols and Acid Hydrolysates}

The analysis of polyols and acid hydrolysates in the incubation media is similar to that which we have used previously (Newell et al., 1980) but with some modifications of the procedure to ensure complete dehydration of the sample prior to derivatisation. Approximately $85 \%$ of the dried sample was inorganic material, mostly representing salt, and this is carried over principally into the ethanol soluble fraction where it can interfere with the derivatisation of polyols. Sodium chloride does not in itself interfere with the analysis of polysaccharides, and up to $1 \mathrm{M} \mathrm{NaCl}$ is often added in GLC analyses of carbohydrates to inhibit hydrogen ion bonding of hydrolysed polysaccharides (Churms, pers comm.).

Weighed samples of $400-500 \mathrm{mg}$ of freeze-dried material were placed in $250 \mathrm{ml}$ round bottom flasks and refluxed for $2 \mathrm{~h}$ in $100 \mathrm{ml} 80 \%$ ethanol. The contents were then centrifuged at $800 \times \mathrm{g}$ for $10 \mathrm{~min}$ and the supernatant containing the ethanol soluble fraction (comprising mainly polyols) was transferred to a $250 \mathrm{ml}$ flask. The sediment was retained for subsequent paper chromatographic identification of sugars.

\section{Ethanol Soluble Fraction}

The supernatant was dried with a Rotovaporator under vacuum at $<45^{\circ} \mathrm{C}$, washed with $20 \mathrm{ml}$ Analar methanol and redried. The contents of the flask were then rewashed and redried twice with Analar methanol. Subsequently, $500 \mu$ l erythritol made up in $100 \mathrm{mg} 100^{-1} \mathrm{ml}$ of distilled water was added and the contents of the flask washed down with $20 \mathrm{ml}$ distilled water. The dried sample was then derivatised for $3 \mathrm{~h}$ at room temperature in $850 \mu \mathrm{l}$ anhydrous pyridine, $100 \mu \mathrm{l}$ hexamethyldisilizane (HMDS) and $50 \mu \mathrm{l}$ trimethyl- chlorosilane (TMS) to form silylating groups. The derivatised sample was then centrifuged at $800 \times \mathrm{g}$ for $10 \mathrm{~min}$ and $10 \mu \mathrm{l}$ samples of the supernatant injected into a Pye-Unicam Series 104 Chromatograph for temperature-programmed analysis as described by Newell et al. (1980).

Ethanol Insoluble Fraction

All components contained in this fraction were identified by paper chromatography (see also Newell et al., 1980).

\section{CHN Analysis}

The total carbon and nitrogen content of the samples was measured with a Carlo Erba elemental analyser (Model 1106) fitted with an integrator to give peak area. Samples of $100-200 \mu \mathrm{g}$ dried sample were weighed into tin containers with a Cahn 25 electrobalance and placed in an auto-sampler which deposited each container sequentially into the combustion reactor at $1050^{\circ} \mathrm{C}$. The nitrogen and carbon content of 5 blank samples of tin cups alone, and of triplicate experimental samples, was then calculated from the mean peak areas of 10 weighed samples of approximately $1.5 \mathrm{mg}$ Acetanilide standard $\left(\mathrm{C}_{6} \mathrm{H}_{5}-\mathrm{NH}\right.$. $\mathrm{COCH}_{3}$ ) which contains $10.36 \%$ nitrogen and $71.09 \%$ carbon.

\section{RESULTS}

We have recently shown that as much as $25 \%$ of the annual energy production by a small kelp bed is released as mucilage from the tips of the fronds during fragmentation and that the concentration of dissolved organic matter may vary considerably over periods of less than $24 \mathrm{~h}$ in the adjacent water column (Newell et al., 1980). This suggests that heterotrophic utilisation of the mucilage may be rapid under natural conditions, but there has been no direct experimental evidence to show which components, if any, are capable of utilisation. In the first instance we have therefore analysed the gross losses of dissolved organic carbon in the incubation media and have subsequently assayed the losses of component mannitol, sugars and alginates which together make up the principal carbohydrates of kelp mucilage.

\section{Utilisation of Dissolved Organic Carbon from Kelp Mucilage}

The organic carbon content of media to which $6.4 \mathrm{~g}$ $\mathrm{l}^{-1}$ dried mucilage from Ecklonia maxima and $7.2 \mathrm{~g} \mathrm{l}^{-1}$ 

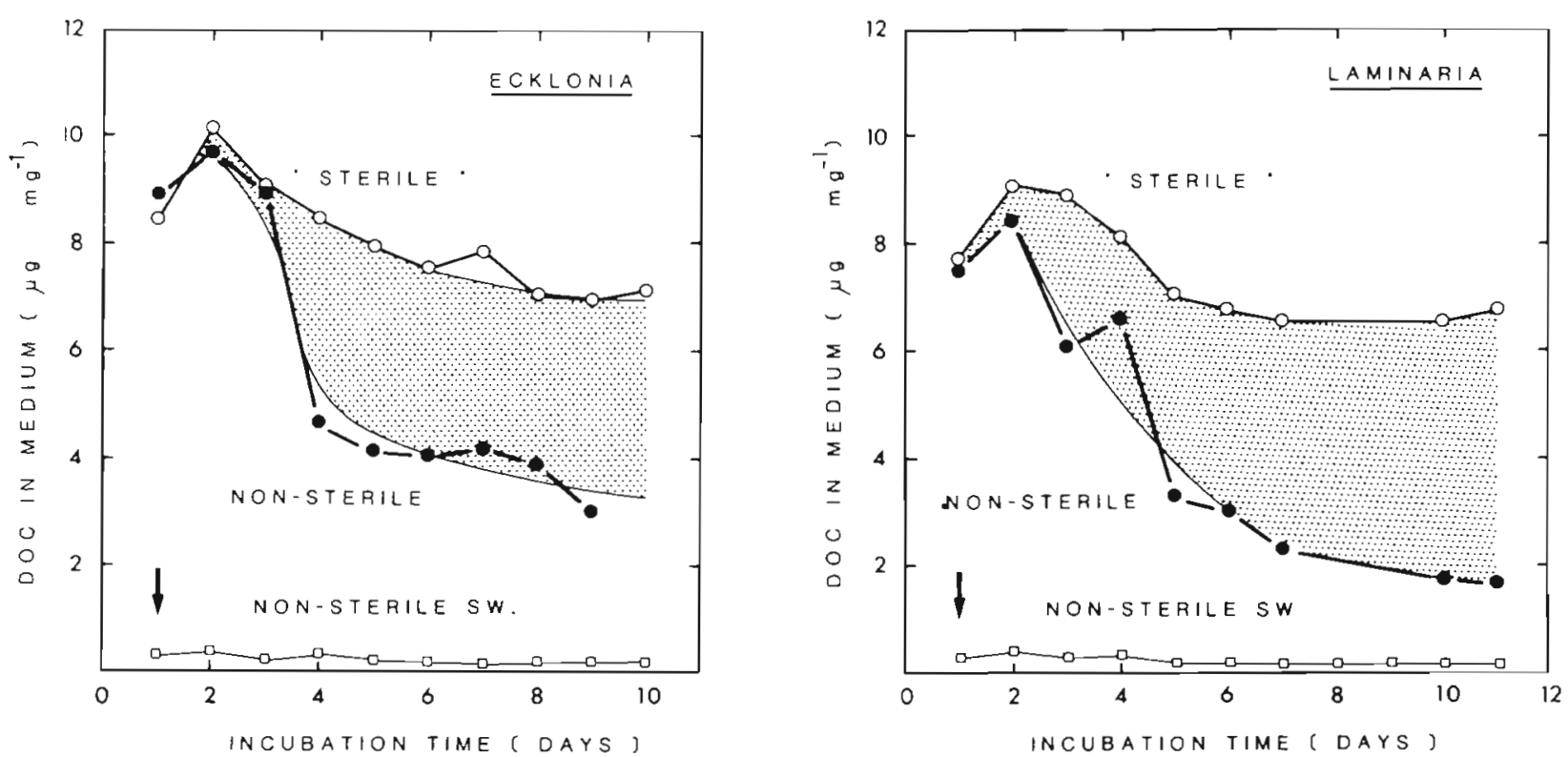

Fig. 1. Organic carbon content of media ( $\mu \mathrm{g} \mathrm{mg}^{-1} \mathrm{dry}$ sample) to which $6.4 \mathrm{~g} \mathrm{l}^{-1}$ dried mucilage from Ecklonia maxima and $7.2 \mathrm{~g}$ $1^{-1}$ from Laminaria pallida had been added. Non-sterile: natural seawater collected from kelp bed in August (winter) to which no mucilage had been added; sterile: mucilage and seawater initially sterilised prior to addition of kelp mucilage. All media incubated at $10^{\circ} \mathrm{C}$ for $10-11 \mathrm{~d}$. Difference between non-sterile and sterile control media shaded. Arrow: start of incubation

from Laminaria pallida had been added is shown in Figure 1. The data are expressed as $\mu \mathrm{g}$ carbon $\mathrm{mg}^{-1}$ dried sample of incubation medium. The first samples were taken shortly after the mucilage had been added to natural kelp-bed seawater collected in August 1979 (winter) and were subsequently made at daily intervals following incubation at $10^{\circ} \mathrm{C}$ for up to $11 \mathrm{~d}$. The values for flasks containing non-sterile seawater are shown as well as data for flasks containing mucilage added to seawater which had been initially filtered with a $2 \mu \mathrm{m}$ filter and autoclaved in the flasks to give 'sterilised control vessels. These tended to become contaminated with bacteria during the course of incubation.

It is evident that mucilage from both Ecklonia maxima and Laminaria pallida can rapidly be utilised and that the major decrease in organic carbon occurred within 3-4 d of the addition of mucilage to unsterilised seawater. Clearly, the difference between the sterilised and non-sterilised media yields the net utilisation of dissolved organic carbon by a population of micro-
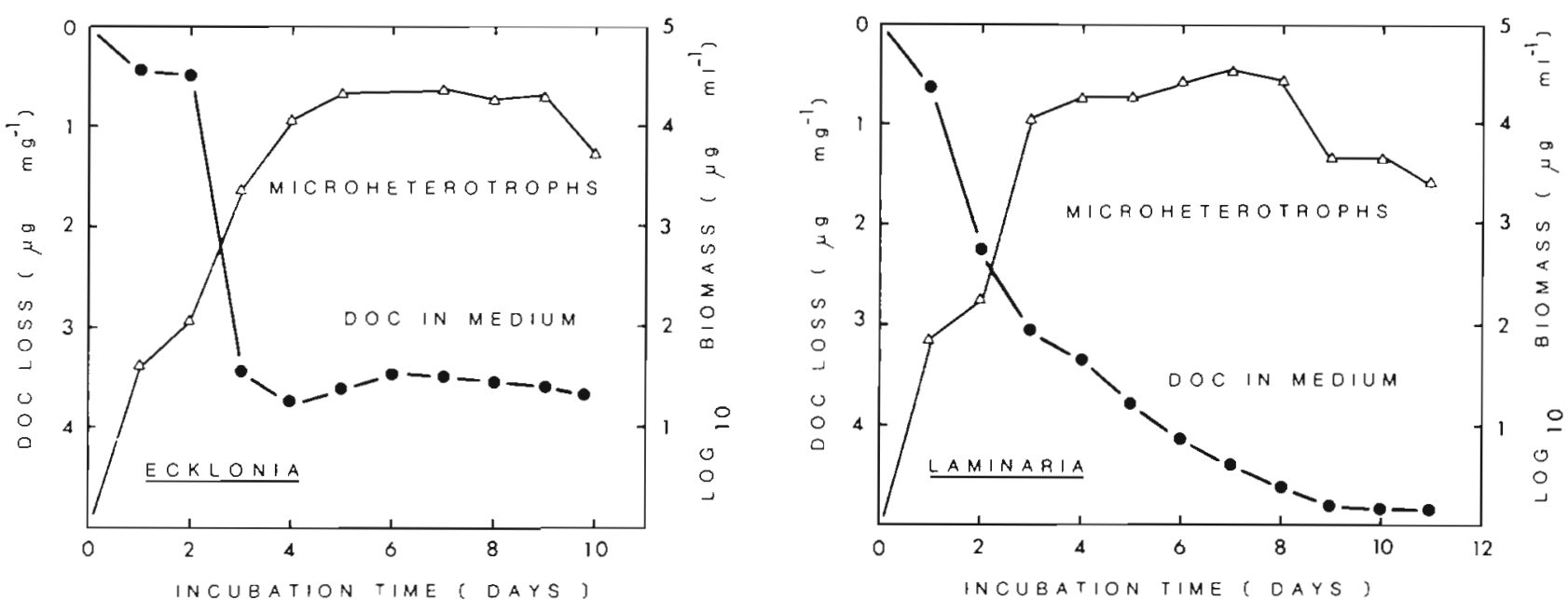

Fig. 2. Net utilisation of dissolved organic carbon ( $\mu \mathrm{g} \mathrm{mg}^{-1} \mathrm{dry}$ sample) and corresponding increase in biomass of microhetero-

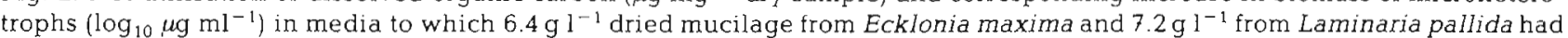
been added prior to incubation for up to $11 \mathrm{~d}$ at $10^{\circ} \mathrm{C}$. Data for carbon loss from Figure 1; data for biomass of microheterotrophs from Linley et al. (1981) 

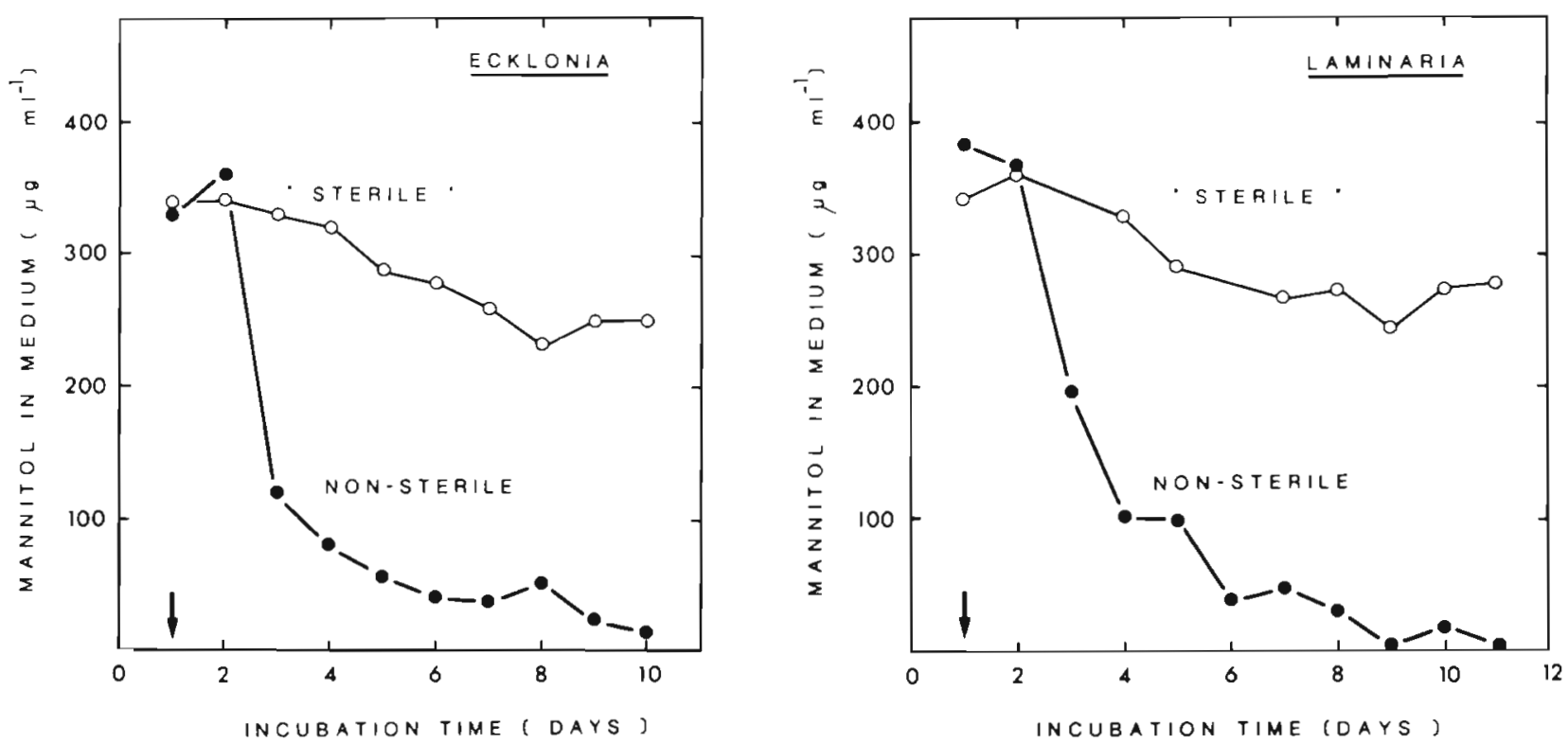

Fig. 3. Concentration of D-mannitol $\left(\mu \mathrm{g} \mathrm{ml} \mathrm{m}^{-1}\right)$ in seawater and sterilısed control flasks to which $6.4 \mathrm{~g} \mathrm{l}^{-1} \mathrm{dried} \mathrm{mucilage} \mathrm{from}$ Ecklonia maxima and $7.2 \mathrm{~g}^{-1}$ from Laminaria pallida had been added prior to incubation for up to $11 \mathrm{~d}$ at $10^{\circ} \mathrm{C}$. Arrows: start of incubation

heterotrophs whose biomass was estimated synchronously and has been described in the previous paper by Linley et al. (1981). The net loss of organic carbon from the media obtained by subtraction of the smoothed curves shown in Figure 1, and the simultaneous increase in total microheterotrophs is shown in Figure 2. The kelp mucilage evidently provides a substrate for micro-organisms, and the fact that the principal losses of dissolved organic carbon occur within the first $3 d$ suggests that the mucilage is utilised principally by the bacterial component which initially dominates the microheterotrophic community (Linley et al., 1981).

\section{Sequential Utilisation of Specific Components of Mucilage}

Although the data cited above allow some estimates to be made of the loss of dissolved organic carbon which accompanies a known increase of bacterial biomass, they give little indication of whether all components of the rather complex substrate provided by kelp mucilage is capable of utilisation. The principal carbohydrates are represented by D-mannitol, sugars and alginates (Newell et al., 1980).

\section{D-mannitol}

The concentration of D-mannitol from the experimental media and sterilised control flasks over a period of up to $11 \mathrm{~d}$ incubation at $10^{\circ} \mathrm{C}$ is shown in Figure 3. The rate of loss of mannitol is evidently initially high, the concentration declining to less than $50 \%$ of its initial value in approximately $48 \mathrm{~h}$. Utilisation subsequently declines asymptotically in mucilage from both kelps and approaches zero after some 9-10d incubation at $10^{\circ} \mathrm{C}$. The correspondence between the loss of D-mannitol from the incubation media and the rapid increase of bacterial biomass suggests that Dmannitol, which represents as much as $77 \%$ of the total sugars plus polyols in kelp mucilage, forms a principal substrate for the bacterial communities which initially colonise mucilage.

\section{Sugars and Alginates}

The presence of fucose, galactose and mannose in the incubation media was positively indicated by paper chromatography of the ethanol insoluble carbohydrate fraction. These sugars were estimated quantitatively by the colorimetric phenol-sulphuric acid reaction method of Dubois et al. (1956). This gives an orange-yellow in the presence of simple sugars, oligosaccharides and polysaccharides, as well as a weaker colour response with uronic acids (see p. 45). The method can thus conveniently be used to estimate mixtures of sugars and their derivatives but it is difficult to isolate the contribution of each component particularly when, as is likely to happen in our incubation experiments, there is a change in the relative concentration of each component with time. Accord- 

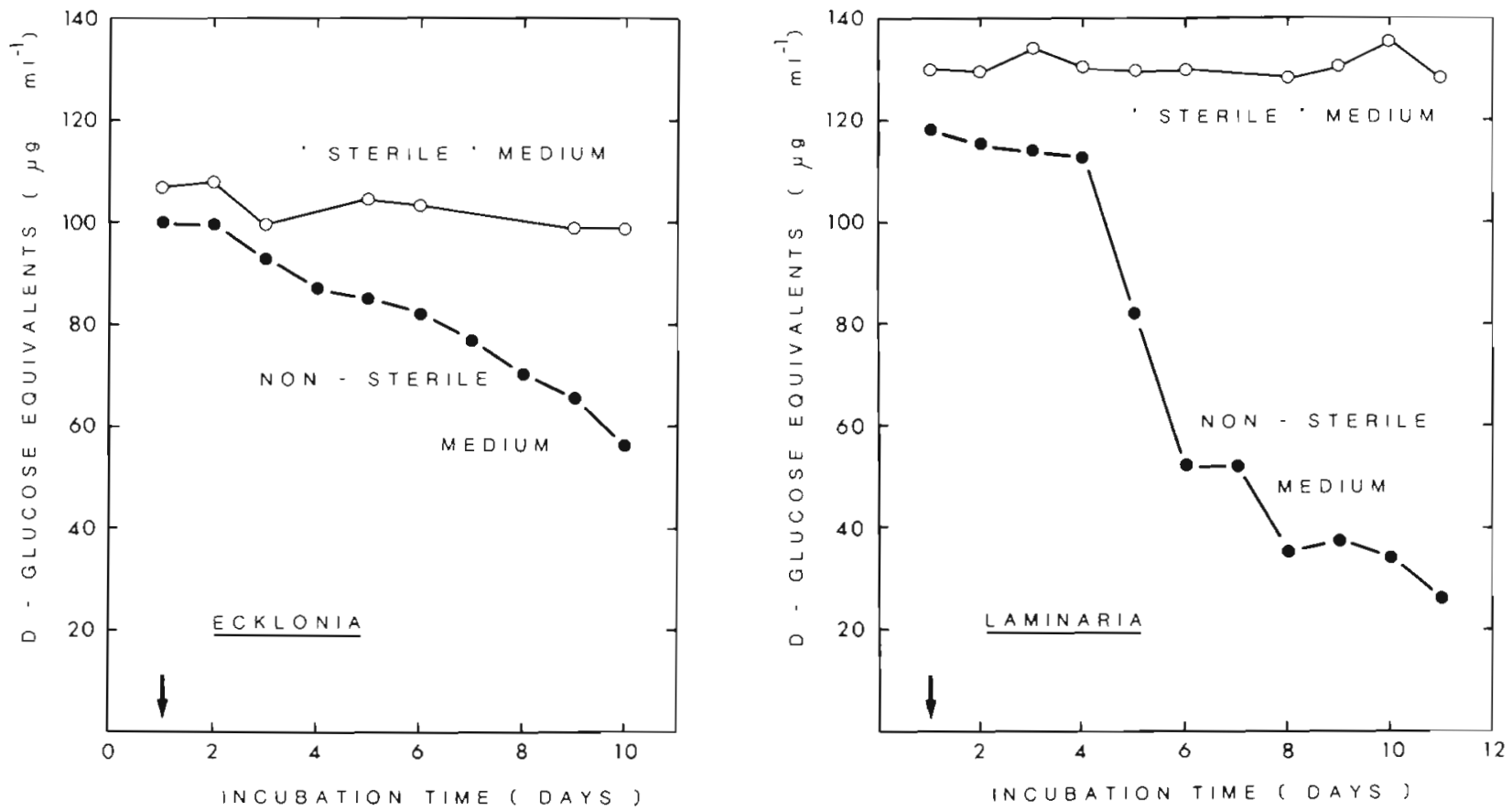

Fig. 4. Concentration of sugars plus alginates (expressed as glucose equivalents, $\mu \mathrm{gl}^{-1}$ ) in seawater and sterilised control flasks to which $6.4 \mathrm{~g} \mathrm{l}^{-1}$ dried mucilage from Ecklonia maxima and $7.2 \mathrm{~g} \mathrm{l}^{-1}$ from Laminaria pallida had been added prior to incubation for up to $11 \mathrm{~d}$ at $10^{\circ} \mathrm{C}$. Arrows: start of incubation

ingly, we have expressed the total simple sugars, oligosaccharides, polysaccharides and their derivatives in terms of 'glucose equivalents' relative to the colour response of $\mathrm{D}$-glucose.

The loss of sugars and uronic acids from the incubation media is shown in Figure 4 . In the case of media containing $6.4 \mathrm{~g}^{-1}$ dried mucilage from Ecklonia maxima, the rate of loss of sugars was negligible initially and then slow compared with that of mannitol so that even after $10 \mathrm{~d}$ incubation at $10^{\circ} \mathrm{C}$ the concentration of sugars had been scarcely reduced to $50 \%$ of its initial value. Equally, in the media containing $7.2 \mathrm{~g} \mathrm{l}^{-1}$ dried mucilage from Laminaria pallida, utilisation was initially very slow over the first $4 \mathrm{~d}$ during which time the mannitol had been reduced to approximately $25 \%$ of its initial concentration. The rate of utilisation of sugars subsequently increased, suggesting that it was utilised as a substrate by heterotrophs only after the concentration of mannitol had become limiting. The concentration of sugars in the $L$. pallida mucilage incubation experiment thus fell to $50 \%$ of the initial value after approximately $5.5 \mathrm{~d}$ compared with a value of only $48 \mathrm{~h}$ for D-mannitol.

These data for the loss of component carbohydrates from the incubation media containing $6.4 \mathrm{~g} \mathrm{l}^{-1}$ dried mucilage from Ecklonia maxima and $7.2 \mathrm{~g} \mathrm{l}^{-1}$ from Laminaria pallida suggest, therefore, that the turnover times of D-mannitol, sugars and alginates differ according to their structural complexity. Bacteria dominated the microheterotrophic community up to Day 8 of incubation at $10^{\circ} \mathrm{C}$ and it is evident that over this period of time the major substrates utilised were mannitol over the first $2-3 \mathrm{~d}$ of incubation with an increasing contribution from sugars from Day 3

Table 1 In!tial concentratıon and time for $50 \%$ utılisation of D-mannitol and sugars plus alginates in incubation media Contaning seawater plus $6.4 \mathrm{~g} \mathrm{l}{ }^{1}\left(=1.93 \mathrm{gl}^{-1}\right.$ organıc matter $)$ dried muclage from Ecklonia maxima and $7.2 \mathrm{~g} \mathrm{l}^{-1}\left(=2.18 \mathrm{~g} \mathrm{l^{-1 }}\right.$ organic matter) from $L$ pallida. Data for seawater collected during August (winter) and incubated at $10^{\circ} \mathrm{C}$

\begin{tabular}{|c|c|c|c|c|}
\hline \multirow[t]{2}{*}{ Component } & \multicolumn{2}{|c|}{ Ecklonia maxima } & \multicolumn{2}{|c|}{ Laminaria pallida } \\
\hline & 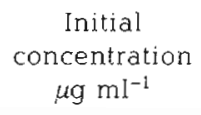 & $\begin{array}{c}\text { Time for } 50 \% \\
\text { utilisation at } \\
10^{\circ} \mathrm{C}\end{array}$ & $\begin{array}{c}\text { Initial } \\
\text { concentration } \\
\mu \mathrm{g} \mathrm{ml^{-1 }}\end{array}$ & $\begin{array}{c}\text { Time for } 50 \% \\
\text { utilisation at } \\
10^{\circ} \mathrm{C}\end{array}$ \\
\hline D-mannitol & 360 & $48 \mathrm{~h}$ & 385 & $48 \mathrm{~h}$ \\
\hline Sugars + alginates & 100 & $360 \mathrm{~h}$ & 118 & $144 \mathrm{~h}$ \\
\hline
\end{tabular}


onwards. The relative utilisation rates of the principal component carbohydrates are summarised in Table 1.

\section{Changes in Carbon and Nitrogen During Incubation}

Carbon and nitrogen analyses have long been used as a convenient estimate of the structural elements relative to protein content in the degradation of plant material and in marine soils. Carbon:nitrogen ratios as high as 100 in fresh leaves, 16-18 in seagrasses, 20 in Rhodophyceae, 6-7 for diatoms and Chlorophyceae, and 5 in bacteria have been cited by Fenchel and Blackburn (1979). Luria (1960) cites values of 3.8-6.2 for the $\mathrm{C} / \mathrm{N}$ ratios of bacteria. The values for marine detritus vary from approximately 30 to 5 , depending on the population of micro-organisms which has colonised the material (Newell, 1965, 1979). The change in this ratio thus reflects both an increase in the nitrogen content contained in the micro-organisms and the simultaneous loss of carbon which is used as a substrate for bacterial growth. It can be used to estimate both the quantitative conversion of nitrogen from mucilage into micro-organisms and the loss of substrate per unit increase of bacterial biomass in the incubation media.

The percentage of nitrogen, carbon and the $\mathrm{C} / \mathrm{N}$ ratio in dried samples of incubation media containing an initial concentration of $6.4 \mathrm{~g} \mathrm{l}^{-1}$ dried mucilage from Ecklonia maxima and $7.2 \mathrm{~g} \mathrm{l}^{-1}$ from Laminaria pallida are shown in Table 2. The seawater was collected from the kelp bed in August 1979 (winter) and incubated for $10-11 \mathrm{~d}$ at $10^{\circ} \mathrm{C}$. It can be seen from both 'sterile' control media and the initial values for those containing mucilage in unsterilised seawater, that the nitrogen content of the E. maxima mucilage was somewhat lower than that of L. pallida whilst the carbon content was rather higher. This is reflected in the $\mathrm{C} / \mathrm{N}$ ratios which are consistently higher in the E. maxima media than in those containing mucilage from L. pallida.

During incubation with unsterilised seawater there was evidently an approximately $25 \%$ loss of nitrogen from the media containing Ecklonia maxima mucilage and a $20 \%$ loss from those containing Laminaria pallida mucilage. This was accompanied by a carbon loss of $57 \%$ in the E. maxima media after a period of $10 \mathrm{~d}$ and as much as $75 \%$ in the L. pallida media following incubation for up to $11 \mathrm{~d}$ at $10^{\circ} \mathrm{C}$. The $\mathrm{C} / \mathrm{N}$ ratio of the E. maxima media thus fell from 10.5 to 5.4 following incubation for $10 \mathrm{~d}$ whilst that of the L. pallida media fell from its initial value of 5.9 to 2.6 over a period of $11 \mathrm{~d}$.

These differences in the carbon utilisation and nitrogen content of the media containing mucilage from
Table. 2. Percentage nitrogen and carbon in dried samples of seawater collected in August (winter) and incubated for up to $11 \mathrm{~d}$ with an initial concentration of $6.4 \mathrm{~g} \mathrm{l}^{-1}$ dried mucilage from Ecklonia maxima and $7.2 \mathrm{~g}^{-1}$ from Laminaria pallida. Data are also shown for control samples incubated in seawater initially sterilised prior to incubation. Each point represents the mean of 3 estimations. Standard deviations were less than $\pm 7 \%$ of the mean for nitrogen and carbon. $\mathrm{C} / \mathrm{N}$ ratios are also shown. Percentage values $\times 10=\mu \mathrm{g}$ carbon or nitrogen per mg sample

\begin{tabular}{|c|c|c|c|c|c|c|}
\hline \multirow[t]{2}{*}{ Days } & \multicolumn{3}{|c|}{ 'Sterile' control } & \multicolumn{3}{|c|}{ Non-sterile seawater } \\
\hline & $\% \mathrm{~N}$ & $\% \mathrm{C}$ & $\mathrm{C} / \mathrm{N}$ & $\% N$ & $\% \mathrm{C}$ & $\mathrm{C} / \mathrm{N}$ \\
\hline \multicolumn{7}{|c|}{ Ecklonia maxima } \\
\hline 1 & 0.13 & 1.21 & 9.30 & 0.143 & 1.51 & 10.50 \\
\hline 2 & 0.13 & 1.38 & 10.61 & 0.116 & 1.19 & 10.20 \\
\hline 3 & 0.11 & 1.08 & 9.82 & 0.136 & 1.35 & 9.90 \\
\hline 4 & 0.12 & 1.30 & 10.83 & 0.106 & 0.78 & 7.36 \\
\hline 5 & 0.11 & 1.30 & 11.82 & 0.103 & 0.78 & 7.60 \\
\hline 6 & 0.18 & 1.14 & 6.33 & 0.156 & 0.84 & 5.40 \\
\hline 7 & 0.09 & 1.18 & 13.11 & 0.140 & 0.74 & 5.30 \\
\hline 8 & 0.07 & $(0.71)$ & - & 0.112 & 0.67 & 5.98 \\
\hline 9 & 0.10 & 1.06 & 10.60 & 0.107 & 0.61 & 5.65 \\
\hline 10 & 0.06 & 1.13 & 18.83 & 0.120 & 0.65 & 5.40 \\
\hline \multicolumn{7}{|c|}{ Laminaria pallida } \\
\hline 1 & $(0.05)$ & 1.09 & - & 0.15 & - & - \\
\hline 2 & 0.19 & 1.01 & 5.30 & 0.21 & 1.24 & 5.90 \\
\hline 3 & 0.17 & 0.87 & 5.10 & 0.18 & 0.88 & 5.00 \\
\hline 4 & 0.17 & 0.75 & 4.41 & 0.19 & 0.82 & 4.37 \\
\hline 5 & 0.17 & 0.90 & 5.30 & 0.17 & 0.63 & 3.75 \\
\hline 6 & 0.17 & 0.79 & 4.65 & 0.18 & 0.54 & 3.02 \\
\hline 7 & 0.16 & 0.77 & 4.82 & 0.16 & 0.46 & 2.91 \\
\hline 8 & 0.15 & 0.72 & 4.80 & 0.18 & 0.49 & 2.79 \\
\hline 9 & 0.18 & 1.02 & 5.67 & 0.17 & 0.40 & 2.40 \\
\hline 10 & 0.15 & 0.77 & 5.13 & 0.15 & 0.34 & 2.33 \\
\hline 11 & 0.14 & 0.69 & 4.93 & 0.14 & 0.32 & 2.26 \\
\hline
\end{tabular}

Ecklonia maxima and Laminaria pallida are clearly related to the biomass of micro-organisms which colonise the two incubation media. Linley et al. (1980) have shown that the biomass of micro-organisms in the media containing $6.4 \mathrm{~g} \mathrm{l}^{-1}$ dried mucilage from $E$. maxima reached only $23 \mu \mathrm{g} \mathrm{ml}^{-1}$ on Day 7 whereas the biomass in media containing $7.2 \mathrm{~g} \mathrm{l}^{-1}$ dried mucilage from L. pallida reached $33 \mu \mathrm{ml}^{-1}$ on Day 7 . We obtained $\mathrm{C} / \mathrm{N}$ ratios of $3.7-4.8$ in mixed micro-organisms sedimented from our culture media. The $\mathrm{C} / \mathrm{N}$ ratios attained towards the end of the experiment thus approach those obtained for microorganisms (see also Luria, 1960) and suggest that transfer of nitrogen from mucilage into the micro-organisms is complete by that time. From the data summarised in Table 2, it is evident that the decline in $\mathrm{C} / \mathrm{N}$ ratios primarily reflects utilisation of dissolved organic carbon from the incubation media.

In a subsequent incubation experiment carried out in February 1980 (summer), the freeze-dried mucilage from Laminaria pallida had been stored before cultur- 
Table 3. Percentage nitrogen and carbon in dried samples of seawater collected in February (summer) and incubated for up to 14 d with an initial concentration of $7.2 \mathrm{~g}^{-1}$ dried mucilage from Laminaria pallida. Data are also shown for control samples incubated in seawater initially sterilised prior to incubation. Each point represents the mean of 3 estimations. Standard deviations were less than $\pm 5 \%$ of the mean for nitrogen and carbon. $\mathrm{C} / \mathrm{N}$ ratios are also shown. Percentage values $\times 10$ $\mu \mathrm{g}$ carbon or nitrogen per mg sample

\begin{tabular}{|c|c|c|c|c|c|c|c|}
\hline \multirow[t]{2}{*}{ Days } & \multicolumn{3}{|c|}{ 'Sterile' control } & \multirow[t]{2}{*}{ Days } & \multicolumn{3}{|c|}{ Non-sterile seawater } \\
\hline & $\% N$ & $\% \mathrm{C}$ & $\mathrm{C} / \mathrm{N}$ & & $\% \mathrm{~N}$ & $\% \mathrm{C}$ & $\mathrm{C} / \mathrm{N}$ \\
\hline 1 & 0.11 & 1.09 & 9.9 & 1 & 0.095 & 0.937 & 9.86 \\
\hline 2 & 0.10 & 0.76 & 7.6 & 2 & 0.100 & 0.920 & 10.10 \\
\hline 3 & 0.12 & 1.10 & 9.16 & 3 & 0.110 & 0.875 & 7.95 \\
\hline 4 & 0.11 & 0.98 & 8.91 & 4 & 0.090 & 0.680 & 7.55 \\
\hline 5 & 0.11 & 1.24 & 11.2 & 5 & 0.086 & 0.540 & 6.27 \\
\hline 6 & 0.11 & 0.83 & 7.54 & 6 & 0.073 & 0.366 & 5.01 \\
\hline 7 & 0.12 & 1.04 & 8.67 & 7 & 0.066 & 0.330 & 5.00 \\
\hline 8 & - & 0.87 & - & 8 & 0.125 & 0.426 & 3.66 \\
\hline 9 & 0.08 & 0.75 & 9.4 & 9 & 0.123 & 0.386 & 3.14 \\
\hline 10 & 0.09 & - & - & 10 & 0.076 & 0.266 & 3.50 \\
\hline 11 & 0.08 & - & - & 11 & 0.070 & 0.223 & 3.18 \\
\hline 12 & 0.09 & 0.94 & 10.4 & 12 & 0.050 & 0.195 & 3.80 \\
\hline 13 & 0.08 & 0.94 & 10.4 & 13 & 0.070 & 0.265 & 3.78 \\
\hline 14 & - & - & - & 14 & 0.075 & 0.270 & 3.60 \\
\hline
\end{tabular}

ing for $14 \mathrm{~d}$ in freshly collected seawater from the kelp bed. The results are summarised in Table 3. The initial carbon and nitrogen values evidently reflect a loss of nitrogen from the freeze-dried material over the storage period of 6 months, resulting in a $\mathrm{C} / \mathrm{N}$ ratio which was as high as 10 on Day 2 and which was rather similar to that of the freshly prepared Ecklonia maxima mucilage shown in Table 2. Subsequently there was a loss of approximately $25 \%$ of the nitrogen coupled with a loss of $71 \%$ of the carbon associated with the development of a population of microheterotrophs which reached approximately $91 \mu \mathrm{g} \mathrm{ml}^{-1}$.

Approximately $75 \%$ of the nitrogen in the added mucilage thus appears to be converted into microbial biomass in all incubation media, with a rather higher conversion of $80 \%$ from the freshly-prepared mucilage from Laminaria pallida. This is accomplished with a corresponding utilisation of the component carbohydrates in the mucilage. The losses of D-mannitol, sugars and alginates, as well as values for carbon in the incubation media associated with a known increase in microbial biomass, can now be used to calculate the conversion efficiency in the first step of the food chain from kelp exudates to bacteria.

\section{Conversion of Kelp Mucilage to Microbial Biomass}

The net utilisation of carbon from incubation media containing an initial concentration of $6.4 \mathrm{~g}^{-1}$ dried mucilage from Ecklonia maxima and $7.2 \mathrm{~g} \mathrm{l}^{-1}$ from Laminaria pallida is shown in Table 4 , together with the simultaneous net increase in biomass of heterotrophs (see Linley et al., 1981). It can be seen that in the case of media containing E. maxima mucilage, neg- lecting the period before bacteria appeared in the media, an increase in the microbial biomass from 2.4 on Day 3 to $22.26 \mu \mathrm{g} \mathrm{ml}^{-1}$ on Day 7 is associated with a loss of $173 \mu \mathrm{g} \mathrm{ml}^{-1}$ carbon from the incubation media. The conversion to microbial biomass per unit carbon utilised from the media is thus approximately $11.5 \%$. Similarly, in the case of seawater containing L. pallida mucilage, the conversion efficiency ${ }^{*}$ over the same period of time is approximately $14 \%$.

Because of minor differences in the time at which the microheterotrophic population becomes established in the different media, it is preferable to plot the biomass of heterotrophs as a function of carbon loss. The slope of the line then gives the conversion efficiency for media containing mucilage from both Ecklonia maxima and Laminaria pallida. These data are summarised

\footnotetext{
- The 'conversion efficiency' is commonly expressed in terms of either bacterial carbon synthesised per unit carbon utilised or bacterial biomass per unit dry mass of substrate used. Whilst these are useful for carbon-flow studies, we have been mainly concemed with estimation of the bacterial biomass which can be supported in nearshore waters by annual keip production. It has therefore been convenient to use figures for kelp carbon production in conjunction with our own measured biomass values without recourse to assumptions of the carbon content of the bacteria. The same argument applies to our estimation of the efficiency of conversion of carbon from substrates during incubation and the synchronous increase in bacterial biomass in that the efficiency relates directly to our experimental results without the intervention of assumptions of either the carbon content of the microbial population or, conversely of the mass equivalent of carbon utilisation from the substrate. However, values cited by Luria (1960) suggest that bacterial carbon is commonly $50 \%$ of the dry biomass so that our ratios can, if required for comparison with other data, be easily converted to carbon:carbon ratios by halving the values cited in the text
} 
Table 4. Net utilisation of carbon and corresponding increase in biomass of heterotrophs over a period of up to $11 \mathrm{~d}$ at $10^{\circ} \mathrm{C}$ in incubation media containing $6.4 \mathrm{~g} \mathrm{l}^{-1}$ dried mucilage from Ecklonia maxima and $7.2 \mathrm{~g} \mathrm{l}^{-1}$ from Laminaria pallida. Data represent difference between sterile control and experimental values for carbon and biomass, respectively. $1 \mathrm{ml}$ of medium weighs 42.06 mg. Data for winter (August) seawater incubation experiment

\begin{tabular}{|c|c|c|c|c|}
\hline \multirow[t]{2}{*}{ Days } & \multicolumn{2}{|c|}{ Ecklonia maxima } & \multicolumn{2}{|c|}{ Laminaria pallida } \\
\hline & $\begin{array}{l}\text { Utilisation of } \\
\text { carbon in } \\
\text { medium } \\
\left(\mu \mathrm{g} \mathrm{ml}^{-1}\right)\end{array}$ & $\begin{array}{c}\text { Increase in } \\
\text { biomass of } \\
\text { heterotrophs } \\
(\mu \mathrm{g} \mathrm{mi})\end{array}$ & $\begin{array}{l}\text { Utilisation of } \\
\text { carbon in } \\
\text { medium } \\
\left(\mu \mathrm{g} \mathrm{ml}^{-1}\right)\end{array}$ & $\begin{array}{l}\text { Increase in } \\
\text { biomass of } \\
\text { heterotrophs } \\
\left(\mu \mathrm{g} \mathrm{m}^{-1}\right)\end{array}$ \\
\hline 1 & 0 & 0.04 & - & 0.035 \\
\hline 2 & 82 & 0.095 & - & 0.138 \\
\hline 3 & 182 & 2.368 & 90 & 11.465 \\
\hline 4 & 270 & 11.736 & 149 & 19.579 \\
\hline 5 & 310 & 21.309 & 194 & 19.567 \\
\hline 6 & 338 & $21.80^{\circ}$ & 230 & 25.311 \\
\hline 7 & 355 & 22.260 & 258 & 34.959 \\
\hline 8 & 353 & 18.966 & 282 & 25.749 \\
\hline 9 & 367 & 19.922 & 305 & 4.687 \\
\hline 10 & 373 & 4.711 & 324 & 6.731 \\
\hline 11 & - & - & 340 & 2.417 \\
\hline
\end{tabular}

in Figure 5 which shows that the conversion efficiency of carbon into microbial biomass is similar in media containing mucilage from both E. maxima and L. pallida. The equation of the regression is $Y=$ $0.124 X-20.113(N=5 ; r=0.976 ; \mathrm{P}=>0.99)$ for Ecklonia maxima and $Y=0.121 X-0.059(N=6 ; r=$ $0.972 ; \mathrm{P}=>0.99$ ) for seawater containing mucilage

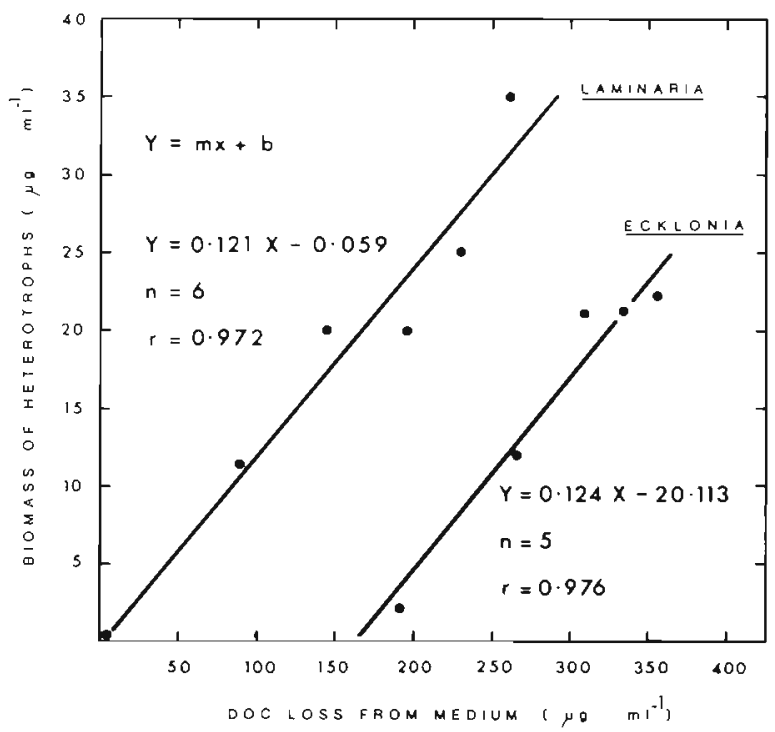

Fig. 5. Relationship between biomass of microheterotrophs $\left(\mu \mathrm{g} \mathrm{ml}^{-1}\right)$ and carbon loss $\left(\mu \mathrm{g} \mathrm{ml}^{-1}\right)$ in seawater to which $6.4 \mathrm{~g}$ $\mathrm{l}^{-1}$ dried mucilage from Ecklonia maxima and $7.2 \mathrm{~g} \mathrm{l}^{-1}$ from Laminaria pallida had been added prior to incubation for up to $11 \mathrm{~d}$ at $10^{\circ} \mathrm{C}$. Equation of the regression for E. maxima is $Y=0.124 X-20.113(n=5 ; r=0.976)$; that for $L$. pallida, $Y=0.121 X-0.059(n=6 ; I=0.972)$. Regression line fitted to linear part of data summarised in Table 4 from $L$. pallida. The increase in microbial biomass per unit carbon loss from the mucilage is thus $12.4 \%$ for $E$. maxima and $12.1 \%$ for L. pallida, the apparent difference between the two media being due to the time lag in the initial establishment of microheterotrophs in the media containing mucilage from E. maxima, rather than any inherent difference in the conversion efficiency of mucilage from the two sources.

Because of the larger biomass of micro-organisms which develops in media containing $7.2 \mathrm{~g} \mathrm{l}^{-1}$ of the same mucilage from Laminaria pallida, but incubated in seawater collected in February (summer), the biomass:carbon conversion ratios are higher during the summer months. The data for net carbon loss from the media and simultaneous increase in microbial biomass (from Linley et al., 1981) at $10^{\circ} \mathrm{C}$ for up to $14 \mathrm{~d}$ is shown in Table 5. It will be noticed that there is an initial utilisation of carbon from the medium prior to the development of a large bacterial biomass and that subsequently the conversion of organic carbon into bacterial biomass increases in efficiency, reaching approximately $68 \%$ between Days 7 and 9 . The apparent conversion efficiency of organic carbon into bacterial biomass thus depends upon the growth phase of the bacteria. For the purposes of estimation of the overall conversion of the products of primary production into bacterial biomass, we feel that it is preferable to include the rather high initial utilisation of organic carbon necessary to initiate bacterial growth, and to calculate conversion efficiency from the regression of bacterial biomass on carbon utilisation over the whole experimental period up to the appearance of grazing Protozoa on Day 9. The equation for the regression of 
Table 5. Net utilisation of carbon and corresponding increase in biomass of heterotrophs over a period of up to $14 \mathrm{~d}$ at $10^{\circ} \mathrm{C}$ in incubation media containing $7.2 \mathrm{~g} \mathrm{l}^{-1}$ dried mucilage from Laminaria pallida. Data represent difference between sterile control and experimental values for carbon and biomass, respectively. $1 \mathrm{ml}$ medium weighs $42.88 \mathrm{mg}$. Data for summer (February) seawater incubation experiment

\begin{tabular}{|rcr|}
\hline Days & $\begin{array}{c}\text { Utilisation of } \\
\text { carbon in medium } \\
\left(\mu \mathrm{g} \mathrm{ml}^{-1}\right)\end{array}$ & $\begin{array}{c}\text { Increase in biomass } \\
\text { of heterotrophs } \\
\left(\mu \mathrm{g} \mathrm{m}^{-1}\right)\end{array}$ \\
\hline 1 & 0 & 0.482 \\
2 & 22.37 & 0.861 \\
3 & 54.04 & 4.329 \\
4 & 109.78 & 8.831 \\
5 & 153.94 & 21.771 \\
6 & 186.36 & 20.207 \\
7 & 212.69 & 29.753 \\
8 & 246.36 & 76.391 \\
9 & 266.36 & 91.739 \\
10 & 287.36 & 80.738 \\
11 & 305.74 & 70.193 \\
12 & 317.74 & 54.708 \\
13 & 287.73 & 35.236 \\
14 & 285.58 & 10.493 \\
\hline
\end{tabular}

heterotroph biomass $\left(\mu \mathrm{g} \mathrm{ml}^{-1}\right)$ on carbon loss $\left(\mu \mathrm{g} \mathrm{ml}^{-1}\right)$ is $Y=0.294 X-12.65(N=9 ; r=0.862 \mathrm{P}=>0.99)$. Since the intercept value is negative, the equation indicates that there is an initial lag before a microbial population is established and that the conversion efficiency of the mucilage from L. pallida is subsequently $29.4 \%$ in seawater collected from the kelp bed during the summer months compared with only $12.1 \%$ for the same mucilage incubated in seawater collected in the winter. Linley et al. (1981) have shown that although the numbers of bacteria are generally similar in the winter and summer incubation media, large bacterial rods predominate in the summer whereas in the winter media are dominated mainly by smaller rods. The bacterial biomass in the summer media is thus almost $3 \times$ that of the winter incubation experiments even though carbon utilisation is comparable from both media.

The sum of the values we have obtained for the loss of mannitol, sugars and alginates provides an independent means of assessing the conversion efficiency and can also be used to confirm whether these components are the principal substrates used by bacteria.

Table 6 shows the net utilisation of D-mannitol, sugars and alginates and the total values, as well as the corresponding net increase in microheterotrophs in media containing $6.4 \mathrm{~g} \mathrm{l}^{-1}$ dried mucilage from Ecklonia maxima and $7.2 \mathrm{~g} \mathrm{I}^{-1}$ from Laminaria pallida incubated at $10^{\circ} \mathrm{C}$ in seawater collected during August (winter). The carbohydrates contain approximately $40 \%$ carbon, so that the net increase in microbial biomass per unit carbon utilised can be calculated from the values for the total substrate utilised. The equation for the regression of microbial biomass on substrate carbon utilised is $Y=0.139 X-0.326(N=7 ; r$ $=0.814 ; \mathrm{P}=>0.95)$ for the media containing mucilage from $E$. maxima and $Y=0.1835 X-1.1819(N=7 ; r$ $=0.965 ; \mathrm{P}=>0.999$ ) for the media containing mucilage from $L$. pallida. That is, the calculated conversion efficiency from known component substrates in mucilage is estimated as $13.9 \%$ for E. maxima mucilage and $18.4 \%$ for L. pallida mucilage, compared with $12.4 \%$ and $12.1 \%$ respectively estimated from carbon utilisation. The slight differences may be due to the fact that sugars and alginates have been estimated in terms of 'glucose equivalents' (see p. 48), but clearly our measurements of the rates of utilisation of the known component carbohydrates of kelp mucilage (see Newell et al., 1980) are in good agreement with estimates based on carbon losses alone and account for the whole of the substrate utilisation by bacteria which colonise the media.

\section{CONCLUSION}

D-mannitol and, to a lesser extent, the sugars plus alginate component of kelp mucilage provide a substrate utilised by bacteria which colonise incubation media containing $6.4 \mathrm{~g} \mathrm{l}^{-1}$ dried mucilage from Ecklonia maxima and $7.2 \mathrm{~g} \mathrm{l}^{-1}$ from Laminaria pallida. There are, however, marked seasonal differences in the biomass of bacteria which accompanies a known loss of substrate. In samples of mucilage incubated at $10^{\circ} \mathrm{C}$ in seawater collected during August (winter) the biomass of bacteria per unit carbon loss was $12.4 \%$ for E. maxima and $12.1 \%$ for L. pallida mucilage. Incubation of the same mucilage from $L$. pallida in seawater collected during February (summer), however, resulted in the development of a population of large rods whose biomass was about $3 \times$ that of the smaller rods which predominated in the winter incubation experiments. The biomass of bacteria per unit carbon loss in these experiments amounted to as much as $29.4 \%$ in the summer incubation experiments.

Although the dried mucilage was extracted from the save plants as those used in the winter inoculation experiments, some loss of nitrogen occurred during storage (see p. 50). The differences in conversion efficiency in winter and summer described above are thus probably related to the types of micro-organisms available for colonisation in seawater at the time of collection. Linley and Field (1981) have shown that the assemblage of bacteria is subject to considerable seasonal variation in kelp-bed seawater. The bacterial biomass is minimal in May, June and July (winter) and is dominated by small free-living cocci, much as in our incubation media made up in seawater collected during early August. From August to October (incl.) the 
Table 6. Sum of carbohydrate utilisation and corresponding increase in biomass of heterotrophs in incubation media containing $6.4 \mathrm{~g} \mathrm{l}^{-1}$ dry mucilage from Ecklonia maxima and $7.2 \mathrm{~g} \mathrm{l}^{-1}$ from Laminaria pallida. Seawater samples taken in August 1979 (winter) and incubated for $10 \mathrm{~d}$. The carbon content of total carbohydrates was estimated at $40 \%$ of the dry weight

\begin{tabular}{|c|c|c|c|c|c|}
\hline \multirow[t]{2}{*}{ Days } & \multicolumn{4}{|c|}{ Substrate utilisation $\left(\mu \mathrm{g} \mathrm{ml}^{-1}\right)$} & \multirow{2}{*}{$\begin{array}{c}\text { Heterotroph } \\
\text { biomass } \\
\left(\mu \mathrm{g} \mathrm{ml}^{-1}\right)\end{array}$} \\
\hline & Mannitol & $\begin{array}{l}\text { Sugars }+ \\
\text { alginates }\end{array}$ & Total & Carbon & \\
\hline \multicolumn{6}{|c|}{ Ecklonia maxima } \\
\hline 1 & - & - & 0 & 0 & 0.04 \\
\hline 2 & - & 99.89 & 99.89 & 39.96 & 0.95 \\
\hline 3 & 212 & 93.06 & 305.00 & 122.0 & 2.37 \\
\hline 4 & 252 & 86.50 & 339.00 & 135.6 & 11.74 \\
\hline 5 & 276 & 85.30 & 361.00 & 144.4 & 21.31 \\
\hline 6 & 292 & 82.84 & 375.00 & 150.0 & 21.80 \\
\hline 7 & 296 & 77.05 & 373.00 & 149.2 & 22.26 \\
\hline 8 & 280 & 70.06 & 350.00 & 140.0 & 18.966 \\
\hline 9 & 308 & 66.48 & 374.00 & 149.6 & 19.922 \\
\hline 10 & 316 & 63.94 & 380.00 & 152.0 & 4.711 \\
\hline \multicolumn{6}{|c|}{ Laminaria pallida } \\
\hline 1 & 0 & 0 & 0 & 0 & 0.035 \\
\hline 2 & 16 & 2.26 & 18.26 & 7.3 & 0.138 \\
\hline 3 & 184 & 3.46 & 187.5 & 75.0 & 11.465 \\
\hline 4 & 284 & 5.29 & 289.3 & 115.7 & 19.579 \\
\hline 5 & 284 & 35.61 & 319.6 & 127.8 & 19.507 \\
\hline 6 & 344 & 65.50 & 409.5 & 163.8 & 25.311 \\
\hline 7 & 336 & 65.50 & 401.5 & 160.6 & 34.959 \\
\hline 8 & 352 & 82.21 & 434.2 & 173.7 & 25.749 \\
\hline 9 & 380 & 80.52 & 460.5 & 184.2 & 4.687 \\
\hline 10 & 364 & 83.83 & 447.8 & 179.1 & 6.731 \\
\hline 11 & 380 & 91.31 & 471.3 & 188.0 & 2.417 \\
\hline
\end{tabular}

Table 7. Annual production of mucilage released during fragmentation from a mixed kelp bed of Ecklonia maxima and Laminaria pallida of 700 ha at Kommetjie, Cape Peninsula, based on data from Newell et al. (1980). The bacterial biomass based on a winter conversion efficiency of $12 \%$ and a summer value of $29 \%$ is shown, together with the biomass of Protozoa (flagellates plus ciliates) at $10 \%$ of the bacterial biomass. (After Linley et al., 1981)

\begin{tabular}{|c|c|c|}
\hline & Ecklonia maxima & Laminaria pallida \\
\hline Annual mucilage production (Newell et al., 1980) & $\begin{array}{l}8.64 \times 10^{10} \mathrm{~kJ} \\
=17.717 \times 10^{7} \mathrm{l}\end{array}$ & $\begin{array}{l}2.1 \times 10^{10} \mathrm{~kJ} \\
=3.848 \times 10^{7} \mathrm{l}\end{array}$ \\
\hline Dry weight of mucilage $\mathrm{l}^{-1}$ & $66.2 \mathrm{~g}$ & $74.2 \mathrm{~g}$ \\
\hline Annual dry mucilage production & $1172.86 \times 10^{4} \mathrm{~kg}$ & $285.52 \times 10^{4} \mathrm{~kg}$ \\
\hline $\begin{array}{l}\text { Annual carbohydrate production at } 25 \% \text { of dry } \\
\text { mucilage production }\end{array}$ & $293.215 \times 10^{4} \mathrm{~kg}$ & $71.38 \times 10^{4} \mathrm{~kg}$ \\
\hline $\begin{array}{l}\text { Carbon at } 40 \% \text { of Carbohydrate } \\
\text { (a) winter at } 12 \% \text { ( } 6 \text { months) } \\
\text { (b) summer at } 29 \% \text { ( } 6 \text { months) }\end{array}$ & $\begin{array}{r}117.286 \times 10^{4} \mathrm{~kg} \\
7.037 \times 10^{4} \mathrm{~kg} \\
17.006 \times 10^{4} \mathrm{~kg}\end{array}$ & $\begin{array}{r}28.552 \times 10^{4} \mathrm{~kg} \\
1.713 \times 10^{4} \mathrm{~kg} \\
4.140 \times 10^{4} \mathrm{~kg} \\
\end{array}$ \\
\hline Sub-total & $24.043 \times 10^{4} \mathrm{~kg}$ & $5.853 \times 10^{4} \mathrm{~kg}$ \\
\hline $\begin{array}{l}\text { Total annual biomass of bacteria from } \\
\text { kelp mucilage }\end{array}$ & \multicolumn{2}{|c|}{$29.896 \times 10^{4} \mathrm{~kg}$} \\
\hline Protozoa at $10 \%$ of bacteria & \multicolumn{2}{|c|}{$2.989 \times 10^{4} \mathrm{~kg}$} \\
\hline
\end{tabular}


bacterial biomass is variable and depends largely on the local periods of upwelling which occur during south-easterly winds at this time of the year. From November to January (incl.) there are strong southeasterly winds and upwelling with a good deal of particulate matter and bacterial aggregates in the water. The bacterial population at this time is heterogeneous with a high biomass and more large rods than in winter. It clearly coincides with the large biomass of bacteria obtained in our incubation experiments at this time of the year, and with a conversion efficiency of $29.4 \%$ for the Laminaria pallida mucilage. The low value of $12 \%$ conversion efficiency obtained in the mucilage incubated in seawater collected in August coincides with the lower biomass of bacteria characteristic of winter and pre-upwelling conditions in the spring. Finally, the period February to April is characterised by a return to a variable biomass of bacteria as the upwelling induced by the south-east winds declines. Estimates of the biomass of microheterotrophs which is likely to be supported by the mucilage released during fragmentation of kelp must therefore take into account both the changes in conversion efficiency by the community which occur with the onset of upwelling conditions in the waters near the kelp bed, as well as energy losses which occur at successive steps in the food chain.

Values for the annual mucilage production during fragmentation from the tips of kelp in a small kelp bed of 700 ha at Kommetjie, Cape Peninsula, have been estimated by Newell et al. (1980) based on the relative proportions of Ecklonia maxima and Laminaria pallida and their wet weight : dry weight ratios. The data are summarised in Table 7 which also shows the equivalent dry weight of annual mucilage production. Carbohydrates comprise approximately $25 \%$ of the dry weight of the mucilage (Newell et al., 1980) whilst the carbon content of the carbohydrates is approximately $40 \%$ of the dry weight. The bacterial biomass can thus be calculated from the carbon equivalent of mucilage production using the conversion efficiencies of $12 \%$ established for winter seawater and $29 \%$ for the summer. Three months of the year coincide with the low winter conversion rates of $12 \%$ and a further three months with the high values of $29 \%$. The remaining six months are of variable production depending on the degree of upwelling which can be assumed to occur $50 \%$ of the time. For the purposes of Table 7 , therefore, a conversion efficiency of $12 \%$ can be assumed for the winter half of the year and $29 \%$ for the summer half. The annual dry weight of mucilage production during fragmentation of $1458.38 \times 10^{4} \mathrm{~kg}$ from the whole kelp bed of $700 \mathrm{ha}$, therefore, is capable of supporting a dry biomass of $29.896 \times 10^{4} \mathrm{~kg}$ of bacteria.
Professor J. G. Field (University of Cape Town) has recently pointed out to us that in some kelp beds, including that at Kommetjie, the relative proportions of Ecklonia maxima and Laminaria pallida may be very different from the kelp beds of the western Cape Peninsula in general. He suggests that annual frond growth in a mixed kelp bed of 700 ha may be represented by $23.0 \times 10^{10} \mathrm{~kJ} \mathrm{Y}^{-1}$ from E. maxima and as much as $22.8 \times 10^{10} \mathrm{~kJ} \mathrm{y}^{-1}$ from L. pallida. In other words, the relative contribution of growth by L. pallida may be higher than we have estimated for a typical kelp bed in our earlier paper (Newell et al., 1980). Nevertheless it is interesting to note that even using these revised figures, annual mucilage production from the kelp bed would yield $3.91 \times 10^{10} \mathrm{~kJ}$ from $E$. maxima and $7.75 \times 10^{10} \mathrm{~kJ}$ from L. pallida and that this in turn would be capable of supporting $32.46 \times 10^{4} \mathrm{~kg}$ dry bacterial biomass per year. That is, the annual dry biomass of bacteria supported through the dissolvedorganic-matter pathway from a mixed kelp bed of 700 ha is likely to be $30-32 \times 10^{4} \mathrm{~kg}$, despite the differences in the relative proportions of E. maxima and $L$. pallida which occur according to local conditions.

Linley et al. (1981) estimated the standing stock of Protozoa which graze on the bacteria to be some $6-10 \%$ of the bacterial biomass. Annual mucilage production released during fragmentation of the kelp is thus likely to support an annual standing stock of approximately $3.0 \times 10^{4} \mathrm{~kg}$ dry mass of flagellates and ciliates in addition to the $30 \times 10^{4} \mathrm{~kg}$ of bacteria. Although the trophic significance of bacteria and Protozoa has not yet been directly established for the larger consumer organisms associated with kelp beds, the scarcity of herbivores and the high biomass of filter- and deposit-feeding organisms which characterise the kelp bed (see Field et al., 1977; Velimirov et al., 1977) suggests that the community as a whole is largely dependent on the flow of energy through these initial stages of the decomposer food chain based on kelp.

Acknowledgements. We are grateful for advice given by Dr. E. Percival of the Chemistry Department, Royal Holloway College, University of London, on methods for the analysis of alginates. Our gratitude is extended also to Professor A. M. Stephen and Dr. S. Churms of the CSIR Carbohydrate Research Unit, University of Cape Town for advice given on Carbohydrate Analyses. We also acknowledge financial support from SANCOR for the initial part of this work at Cape Town, and the award of a Senior Research Fellowship of the Royal Society which enabled completion of the work at Plymouth.

\section{LITERATURE CITED}

Anderson, G. C., Zeutschel, R. P. (1970). Release of dissolved organic matter by marine phytoplankton in coastal and 
offshore areas of the north-east Pacific Ocean. Limnol Oceanogr. 15: 402-407

Berman, T., Holm-Hansen, O. (1974). Release of photoassimilated carbon as dissolved organic matter by marine phytoplankton. Mar. Biol. 28: 305-310

Choi, C. I. (1972). Primary production and release of dissolved organic carbon from phytoplankton in the Western North Atlantic Ocean. Deep Sea Res. 19: 731-735

Crawford, C. C., Hobbie, J. E., Webb, K. L. (1974). The utilisation of dissolved free amino acids by estuarine micro-organisms. Ecology 55: 551-563

Dubois, M., Gilles, K. A., Hamilton, J. K., Rebers, P. A., Smith, F. (1956). Colorimetric method for determination of sugars and related substances. Analyt. Chem. 28: 350-356

Ducklow, H. W. (1977). Influence of sublethal pollutant concentrations on the microbial ecology of living corals. $\mathrm{Ph}$ D. thesis, Harvard University Cambridge

Fenchel, T. M., Jørgensen, B. B. (1976). Detritus food chains of aquatic ecosystems: The role of bacteria. Adv. microbial Ecol. 1: 1-49

Fenchel, T., Blackburn, T. H. (1979). Bacterial and mineral cycling, Academic Press, London

Field, J. G., Jarman, N. G., Dieckmann, G. S., Griffiths, C. L., Velimirov, B., Zoutendyk, P. (1977). Sun, waves, seaweed and lobsters: The dynamics of a west - coast kelp bed. S. Afr. J. Sci. 73: 7-10

Fogg, G. E. (1958). Extracellular products of phytoplankton and the estimation of primary production. Rapp. P.-v. Réun. Cons. perm. int. Explor. Mer 144: 56-60

Fogg, G. (1966). The extracellular products of algae. Oceanogr. mar. Biol. A. Rev. 4: 195-212

Gordon, G. C., Robinson, G. G. C., Hondzel, L. L., Gillespie, D. C. (1973). A relationship between heterotrophic utilisation of organic acids and bacterial populations in West Blue Lake, Manitoba. Limnol. Oceanogr 18: 264-269

Hellebust, J. A. (1965). Excretion of some organic compounds by marine phytoplankton. Limnol. Oceanogr. 10: 192-206

Hobbie, J. E. (1967). Glucose and acetate in fresh water: Concentrations and turnover rates. In: Gotterman, H. L., Clymo, R. S. (eds) Chemical environment in the aquatic habitat. Noord-Hollandsche, N. V., Uitgevers Maatschappij, Amsterdam, pp. 245-251

Hobbie, J. E. (1971). Heterotrophic bacteria in aquatic ecosystems: some results of studies with organic radioisotopes. In: Cairns, J. Jr. (ed.) The structure and function of freshwater microbial communities. (Res. Div. Monogr. 3). Virginia Polytech. Inst. and State Univ. Blacksbury, Virginia, pp. 181-194

Hobbie, J. E., Wright, R. T. (1965). Bioassay with bacterial uptake kinetics: glucose in fresh water. Limnol. Oceanogr. 10: $471-474$

Iturriaga, R. Hoppe, H. G. (1977). Observations of heterotrophic activity on photoassimilated organic matter. Mar. Biol. 40: 101-108

Linley, E. A. S., Field, J. G. (1981). The nature and ecological significance of bacterial aggregation in a nearshore upwelling system. Estuar. \& coast. mar. Sci., in press

Linley, E. A. S., Newell, R. C., Bosma, S. A. (1981). Heterotrophic utilisation of mucilage released during fragmentation of kelp (Ecklonia maxima and Laminaria pallida) I. Development of microbial communities associated with the degradation of kelp mucilage. Mar. Ecol. Prog. Ser. 4: $31-41$
Luria, S. E. (1960). The bacterial protoplasm: composition and organisation. In: Gunsalus, I. C., Stanier, R. Y. (eds) The bacteria, Vol. 1 Academic Press, New York, pp. 1-34

Moshiri, G. A., Crumpton, W. G., Aumen, N. G. (1979). Dissolved glucose in a Bayov estuary, possible sources and utilisation by bacteria. Hydrobiologia 62: (1): 71-74

Nalewajko, C. (1966). Photosynthesis and excretion in various planktonic algae. Limnol. Oceanogr 11,1-10

Newell, R. C. (1965). The role of detritus in the nutrition of two marine deposit-feeders, the prosobranch Hydrobia ulvae and the bivalve Macoma balthica. Proc. Zool. Soc. Lond 144: $25-45$

Newell, R. C. (1979). Biology of intertidal animals, 3rd ed., Marine Ecological Surveys, Faversham, Kent

Newell, R. C., Lucas, M. I., Velimirov, B., Seiderer, L. J. (1980). The quantitative significance of dissolved organic losses following fragmentation of kelp (Ecklonia maxima and Laminaria pallida). Mar. Ecol. Prog. Ser. 2: 45-59

Ogura, M. (1975). Further studies on decomposition of dissolved organic matter in coastal seawater. Mar. Biol. 31: $101-111$

Sieburth, J. McN. (1969). Studies of algal substances in the sea. III. The production of extracellular organic matter by littoral marine algae. J. exp. mar. Biol. Ecol. 3: 290-309

Sinith, W. V. Jr. (1974). The extracellular release of glycolic acid by a marine diatom. J. Phycol. 10: 30-33

Strickland, J. D. H., Parsons, T. R. (1962). On the production of particulate organic carbon by heterotrophic processes in seawater. Deep Sea Res. 8: 221-222

Thomas, J. P. (1971). Release of dissolved organic matter from natural populations of marine phytoplankton. Mar. Biol. 11: 311-323

Vaccaro, R. F., Jannasch, H. W. (1966). Studies on heterotrophic activity in seawater based on glucose assimilation. Limnol. Oceanogr. 11: 596-607

Velimirov, B., Field, J. G., Griffiths, C. L., Zoutendyk, P. (1977). The ecology of kelp bed communities in the Benguela upwelling system. Analysis of biomass and spatial distribution. Helgoländer wiss. Meeresunters. 30: 495-518

Williams, P. J. le B. (1970). Heterotrophic utilisation of dissolved organic compounds in the sea. I. Size distribution of populations and relationship between respiration and incorporation of growth substances. J. mar. biol. Ass. U. K. 50: $859-870$

Williams, P. J. le B. (1973). The validity of the application of simple kinetic analysis to heterogeneous microbial populations. Limnol. Oceanogr, 18: 159-165

Williams, P. J. le B., Gray, R. W. (1970). Heterotrophic utilisation of dissolved organic compounds in the sea. II. Observations on the responses of heterotrophic marine populations to abrupt increases in amino acid concentration. J. mar. biol. Ass. U.K. 50: 871-881

Wright, R. T. (1975). Studies on glycolic acid metabolism by freshwater bacteria. Limnol. Oceanogr. 20: 626-633

Wright, R. T., Hobbie, J. E. (1965). Uptake of organic solutes in lake water. Limnol. Oceanogr. 10: 22-28

Wright, R. T., Hobbie, J. E. (1966). Use of glucose and acetate by bacteria and algae in aquatic ecosystems. Ecology 47 : $447-464$

Wright, R. T., Shah, N. M. (1975). The trophic role of glycolic acid in coastal seawater. I. Heterotrophic metabolism in seawater. Mar. Biol. 33: 175-183 